
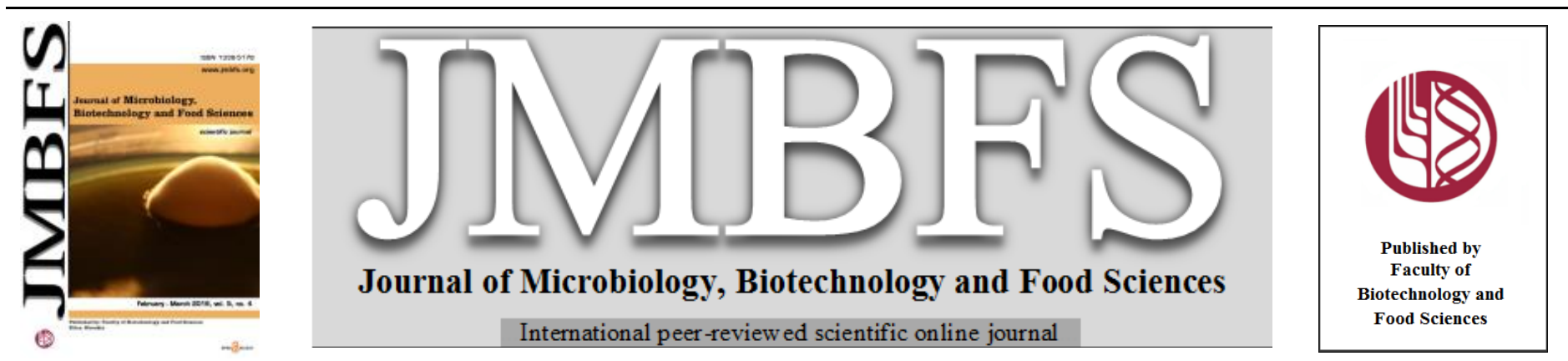

\title{
ASSESSMENT OF RAPD POLYMORPHISM IN RICIN GENOTYPES
}

\section{Želmíra Balážová*, Martin Vivodik, Zdenka Gálová}

Address(es): Mgr. Želmíra Balážová. PhD.,

Slovak University of Agriculture in Nitra. Faculty of Biotechnology and Food Sciences. Department of Biochemistry and Biotechnology. Tr. A. Hlinku 2. 94976

Nitra. Slovak Republic. +421376414327.

*Corresponding author: zelmira.balazova@uniag.sk

doi: 10.15414/jmbfs.2016.5.4.386-388

\section{ARTICLE INFO}

Received 30. 6. 2015

Revised 27. 11. 2015

Accepted 4. 12. 2015

Published 1. 2. 2016

Regular article

OPEN $\partial$ ACCESS

\begin{abstract}
The aim of this work was to detect genetic variability among the set of 30 castor genotypes using 6 RAPD markers. Amplification of genomic DNA of 30 genotypes using RAPD analysis yielded 50 polymorphic fragments with an average of 8.33 fragments per primer. Number of amplified fragments varied from 5 (RLZ7) to 11 (RLZ8) and the amplicon size ranged from 330 to $1200 \mathrm{bp}$. All 50 amplified bands were polymorphic. The polymorphic information content (PIC) values ranged from 0.774 (RLZ7) to 0.870 (RLZ8) with an average of 0.825 and index diversity (DI) value ranged from 0.786 (RLZ7) to 0.872 (RLZ8) with an average of 0.831 . The dendrogram based on hierarchical cluster analysis using UPGMA algorithm was prepared. Dendrogram separated ricin genotypes into three main clusters. Two genotypes (RM-72 and RM-73) were genetically the closest. Knowledge on the genetic diversity of castor can be used for future breeding programs for increased oil production to meet the ever increasing demand of castor oil for industrial uses as well as for biodiesel production.
\end{abstract}

Keywords: Castor, genetic variability, molecular markers, RAPD technique

\section{INTRODUCTION}

Castor (Ricinus communis L., $2 \mathrm{n}=2 \mathrm{x}=20$, Euphorbiaceae), is industrially important non-edible oilseed crop widely cultivated in the arid and semi-arid regions of the world. The seed of castor contains more than $45 \%$ of oil and this oil is rich (80-90\%) in an unusual hydroxyl fatty acid, ricinoleic acid. Castor oil is the only vegetable oil soluble in alcohol, presenting high viscosity, and requiring less heating than others oils during the production of biodiesel (Jeong and Park, 2009). Due to its unique chemical and physical properties, the oil from castor seed is used as raw material for numerous and varied industrial applications, such as: manufacture of polymers, coatings, lubricants for aircrafts, cosmetics, etc, and for the production of biodiesel (Jeong and Park, 2009) with more than $95 \%$ of the world's castor production concentrated in limited parts of India, China, and Brazil (Sailaja et al., 2008). Because of the ever increasing world-wide demand of castor for industrial use, there is a pressing need to increase the hectarage and productivity of castor (Gajeraa et al., 2010).

Castor is a cross pollinated crop and is usually cultivated as a hybrid in India, as hybrids give significantly greater yields than pure lines or varieties (Birchler $\boldsymbol{e t}$ al., 2003; Reif et al., 2007). Higher magnitude of heterosis and genetically superior hybrids can be obtained by combining diverse parents in hybrid development. Conventional diversity analysis methods, in the field, are time consuming, laborious, resource intensive and drastically affected by environmental factors, therefore, a technique that is rapid and not affected by environment is needed for assessment of genetic diversity and selection of parental lines for use in hybrid development programmes (Santalla et al., 1998). Genetic diversity assessment prior to developing hybrids can aid in better exploitation of heterosis. Assessment of genetic variation using molecular markers appears to be an attractive alternative to the conventional diversity analyses and can also aid in management and conservation of biodiversity. A large number of polymorphic markers are required to measure genetic relationships and genetic diversity in a reliable manner (Santalla et al., 1998). DNA-based molecular analysis tools are ideal for germplasm characterization and phylogenetic studies. Among the various DNA-based markers, amplified fragment length polymorphism (AFLP) and restriction fragment length polymorphism (RFLP) have been used to study genetic diversity. These markers elucidate the phylogenetic relationships among various lines, for their efficient use in breeding and genetic resource management. These methods, however, involve the use of expensive enzymes, radioactive labeling which are cumbersome and hence they appear unsuitable (Gajeraa $\boldsymbol{e t}$ al., 2010). Random amplified polymorphic DNA (RAPD) and inter simple sequence repeats (ISSR) markers on the other hand, require only small amounts of DNA sample without involving radioactive labels and are simpler as well as faster. RAPD has been also proven to be simple and quite efficient in detecting genetic variations used for diversity assessment and for identifying germplasm in a number of plant species (Welsh and McClelland, 1990, Gwanama et al., 2000, Kapteyn and Simon, 2002, Gajeraa et al., 2010). ISSR has been shown to provide a powerful, rapid, simple, reproducible and inexpensive means to assess genetic diversity and identify differences between closely related cultivars in many species (Gonzalez et al., 2002, Labajová et al., 2011). Limited studies have been carried out on the genetic diversity and phylogenetics of castor using molecular markers. Recently, studies have been initiated on assessment of genetic variation in castor germplasm using AFLP and SSR markers (Allan et al., 2008).

The aim of this study was to detect genetic variability among the set of 30 castor genotypes using 6 RAPD markers.

\section{MATERIAL AND METHODS}

\section{Plant material and DNA extraction}

Ricin lines (30) were obtained from the breeding station Zeainvent Trnava Ltd. (Slovakia). DNA of 30 castor genotypes was extracted from 10 day old leaves using the Gene JET Plant Genomic DNA Purification Mini Kit (Thermo Scientific).

\section{RAPD amplification}

Amplification of RAPD fragments was performed according to Gajeraa $\boldsymbol{e t}$ al. (2010) (Table 1) using 6 decamer arbitrary primers. Amplifications were performed in a $25 \mu 1$ reaction volume containing $5 \mu \mathrm{l}$ DNA (100 ng), $12.5 \mu \mathrm{l}$ Master Mix (Promega, USA) and $1 \mu 1$ of 10 pmol of primer. Amplification was performed in a thermocycler (Biometra, Germany) with initial denaturation at 94 ${ }^{\circ} \mathrm{C}$ for $5 \mathrm{~min}, 42$ cycles of denaturation at $94{ }^{\circ} \mathrm{C}$ for $1 \mathrm{~min}$, primer annealing at 38 ${ }^{\circ} \mathrm{C}$ for $1 \mathrm{~min}$, extension at $72^{\circ} \mathrm{C}$ for $1 \mathrm{~min}$, and final extension at $72^{\circ} \mathrm{C}$ for $5 \mathrm{~min}$ Amplified products were separated in $1.5 \%$ agarose in $1 \times \mathrm{TBE}$ buffer. The gels were stained with ethidium bromide and documented using gel documentation system UVP PhotoDoc- $\mathrm{t}^{\circledR}$. The size of alleles was determined by comparing with 100 bp standard lenght marker (ThermoFisher Scientific). 
Table 1 List of used RAPD primers

\begin{tabular}{lccl}
\hline Primers & $\begin{array}{c}\text { Primer sequence } \\
\left(5^{\prime}-3^{\prime}\right)\end{array}$ & $\begin{array}{c}\text { Expecting } \\
\text { molecular weight } \\
\text { range (bp) }\end{array}$ & Localization \\
\hline RLZ3 & 5'TGTCCAGCTT 3' & 1200 & 2RL \\
RLZ6 & 5'GTGATCGCAG 3' & 330 & 7RL \\
RLZ7 & 5'GTCCACACGG 3' & 750 & 2RL \\
RLZ8 & 5'GTCCCGACGA 3' & 350 & 7RL \\
RLZ9 & 5'TGCGGCTGAG 3' & 650 & 2RS \\
RLZ10 & 5'ACGCGCATGT 3' & 1100 & 4RL \\
\hline
\end{tabular}

Data analysis

The RAPD bands were scored as present (1) or absent (0), each of which was treated as an independent character regardless of its intensity. The binary data generated were used to estimate levels of polymorphism by dividing the polymorphic bands by the total number of scored bands and to prepare a dendrogram. A dendrogram based on hierarchical cluster analysis using the unweighted pair group method with arithmetic average (UPGMA) with the SPSS professional statistics version 17 software package was constructed.

For the assessment of the polymorphism between ricin genotypes and usability of RAPD markers for differentiation we used diversity index (DI) (Weir, 1990), the probability of identity (PI) (Paetkau et al., 1995) and polymorphic information content (PIC) (Weber, 1990).

They were calculated according to formulas:

\section{Diversity index (DI)}

$D I=1-\sum p_{i}^{2}$

Probability of identity (PI)

$P I=\sum p_{i}^{4}+\sum_{i=1}^{i=n-1} \sum_{j=i+1}^{n}\left(2 p_{i} p_{j}\right)^{2}$

Polymorphic information content (PIC)

$P I C=1-\left(\sum_{i=1}^{n} p_{i}^{2}\right)-\sum_{i=1}^{n-1} \sum_{j=i+1}^{n} 2 p_{i}^{2} \cdot p_{j}^{2}$

where pi and pj are frequencies of ith and jth fragment of given genotype.

\section{RESULTS AND DISCUSSION}

PCR amplifications using 6 RAPD primers produced 50 DNA fragments that could be scored in all genotypes. The selected primers amplified DNA fragments across the 30 genotypes studied with the number of amplified fragments varying from 5 (RLZ7) to 11 (RLZ8) and the amplicon size varied from 330 to $1200 \mathrm{bp}$. Of the 50 amplified bands, all 50 were polymorphic with an average of 8.33 fragments per primer (Table 2). The polymorphic information content (PIC) values varied from 0.774 (RLZ7) to 0.870 (RLZ8) with an average of 0.825 and index diversity (DI) value ranged from 0.786 (RLZ7) to 0.872 (RLZ8) with an average of 0.831 (Table 2). Similar values of DI and the PIC were detected by other authors (Gajeraa et al., 2010; Machado et al., 2013; Tomar Rukam et al., 2014; Vivodík et al., 2014; Kallamadi et al., 2015). Dendrogram based on hierarchical cluster analysis using UPGMA algorithm was prepared. In constructed dendrogram genotypes were divided into three main clusters $(1,2,3)$ Cluster 1 contained unique genotype (RM-76), cluster 2 included two genotypes (RM-62, RM-68) and cluster 3 contained 27 genotypes of ricin. Cluster 3 subdivided 27 genotypes of ricin into two subclusters, subcluster $3 \mathrm{a}$ with unique genotype RM-70 and subcluster $3 \mathrm{~b}$ with 26 genotypes of ricin. Two genotypes of subcluster 3b (RM-72 and RM-73) were genetically the closest (Figure 1). Using more polymorphic RAPD markers genetically close genotypes can be distinguished.

In our study we used 6 RAPD primers to study genetic polymorphism of 30 ricin lines and similar PIC values we obtained as Gajeraa et al. (2010) who used 30 RAPD polymorphic primers for the analysis of 22 castor bean genotypes. We can consider used RAPD primers as sufficiently polymorphic. RAPD analysis of Gajeraa et al. (2010) yielded 256 fragments, of which 205 were polymorphic, with an average of 6.83 polymorphic fragments per primer. Number of amplified fragments with RAPD primers ranged from 6 to 12, with the size of amplicons ranging from 160 to $3000 \mathrm{bp}$ in size. The polymorphism ranged from 27.2 to 100.0 , with an average of $80.2 \%$. Genetic diversity of 37 ricin genotypes grown in China using RAPD markers was studied by Li et al. (2012). Using RAPD markers, together they detected 122 fragments, of which 71 were polymorphic, representing the percentage of polymorphism fragments $58.20 \%$. Dendrogram constructed using UPGMA algorithm divided 37 analyzed ricin genotypes into 4 main clusters. In the study Machado et al. (2013) used 58 RAPD primers for the analysis of 15 castor bean cultivars. The genetic dissimilarity between cultivars was calculated by Jaccard's index, using the unweighted pair-group method with arithmetic mean (UPGMA). Authors identified 552 fragments, of which 311 were polymorphic $(56.3 \%)$. The cultivars were clustered in five groups, evidence that there is genetic difference among them. Authors of their work confirmed, that RAPD markers are efficient in the study of genetic dissimilarity in castor bean.

Table 2 The statistical characteristics of the RAPD markers used in castor

\begin{tabular}{lcccc}
\hline RAPD primer & number of fragments & DI & PIC & PI \\
\hline RLZ3 & 9 & 0.862 & 0.859 & 0.003 \\
RLZ6 & 9 & 0.792 & 0.792 & 0.013 \\
RLZ7 & 5 & 0.786 & 0.774 & 0.036 \\
RLZ8 & 11 & 0.872 & 0.870 & 0.002 \\
RLZ9 & 7 & 0.828 & 0.821 & 0.006 \\
RLZ10 & 9 & 0.842 & 0.837 & 0.005 \\
\hline average & 8.33 & 0.831 & 0.825 & 0.011 \\
\hline
\end{tabular}

DI- diversity index

PIC- polymorphic information content

PI- probability of identity

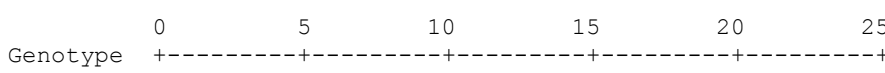

RM-72

$\mathrm{RM}-72$

$\mathrm{RM}-73$

$\mathrm{RM}-69$
$\mathrm{RM}-71$

$\mathrm{RM}-60$

RM- 61

RM-84

RM- 67

$\mathrm{RM}-88$

RM-89

$\mathrm{RM}-75$

RM -77

RM-79

$\mathrm{RM}-87$

RM- 80

$\mathrm{RM}-81$

$\mathrm{RM}-83$

$\mathrm{RM}-63$

$\mathrm{RM}-66$

RM- 65

$\mathrm{RM}-82$

$\mathrm{RM}-78$

RM- 64

$\mathrm{RM}-85$

RM- 86

$\mathrm{RM}-74$

$\mathrm{RM}-70$

$\mathrm{RM}-62$

$\mathrm{RM}-68$

$\mathrm{RM}-76$

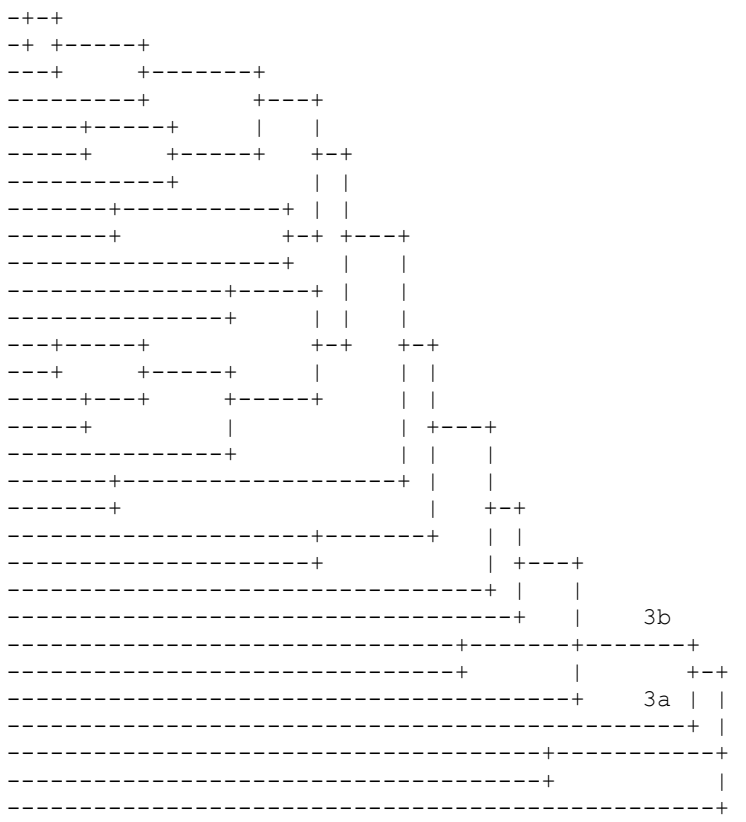

Figure 1 Dendrogram of 30 castor genotypes prepared based on 6 RAPD markers

Tomar Rukam et al. (2014) investigated the fingerprinting and phenotyping of 25 castor genotypes available in Gujarat and other States of India using RAPD and ISSR markers. One hundred thirty decamer RAPD primers from Operon series (OPA to OPZ - five from each series) were screened with the DNA of the two castor genotypes. Only fifty-seven primers generated reproducible and scorable RAPD profiles. These produced multiple band profiles with a number of amplified DNA fragments ranging from 4 to 13 with an average of 7.70 fragments per primer. The total number of fragments produced by the fifty seven primers was 439. Maximum number of 13 amplicons was amplified with primer OPG-04 while the minimum number of fragments (4) was amplified with primer OPQ-01. The number of polymorphic fragments ranged from 0 to 7 . The total number of polymorphic amplicons obtained by the fifty-seven studied primers was 122 . The UPGMA cluster analysis was carried out to represent graphically the genetic distances among the 25 castor genotypes. The obtained dendrogram was divided into three main clusters; cluster one included 19 genotypes while cluster II and III included 5 and 1 genotype, respectively. The main cluster (cluster I) included two subclusters A and B. Subcluster B contained only two 
genotypes i.e. SKI332 and SKI271 while subcluster A contained 17 genotypes which were further divided into subclusters $C$ and D.

RAPD molecular markers have been used in population genetic studies (Parsons et al., 1997, Esselman et al., 1999). Some researchers have considered RAPD markers to represent segments of DNA with noncoding regions (Landergott $\boldsymbol{e}$ al., 2001), and some studies have shown that RAPD markers are distributed throughout the genome and may be associated with functionally important loci (Penner, 1996).

\section{CONCLUSION}

The analysis showed that the RAPD markers are very effective molecular markers for the assessment of the genetic diversity in castor bean. The dendrogram prepared based on UPGMA algorithm divided 30 analyzed genotypes into three main clusters. Using 6 RAPD markers only two castor bean genotypes have not been distinguished (RM-72 and RM-73). For better discrimination of analyzed genotypes of ricin, it is necessary to use a higher number of RAPD markers. Our analysis proved utilization of RAPD markers for differentiation of used set of castor genotypes. We can consider used RAPD primers as sufficiently polymorphic. RAPD markers are useful in the assessmen of castor bean diversity, for the detection of duplicate sample in genotype collection and the selection of a core collection to enhance the efficiency of genotype management for use in castor bean breeding and conservation.

Acknowledgments: This work was funded by European Community under project No. 26220220180: Building Research Centre „AgroBioTech” (50\%) and KEGA project No 021SPU-4/2015 (50\%).

\section{REFERENCES}

Allan, G., Williams, A., Rabinowicz, P.D., Chan, A.P., Ravel, J., Keim, P. (2008). Worldwide genotyping of castor bean germplasm (Ricinus communis L.) using AFLPs and SSRs. Genet. Resour. Crop. Evol., 55, 365-378. http://dx.doi. org/10.1007/s10722-007-9244-3

Birchler, J.A., Auger, D.L., Riddle, N.C. (2003). In search of the molecular basis of heterosis. Plant Cell, 15, 2236-2239. http://dx.doi.org/10.1105/tpc.151030 Esselman, E.J., Li, J.Q., Crawford, D., Winduss, J.L., Wolfe, A.D. (1999). Clona diversity in the rare Calamagrostis porteri ssp. Insperata (Poaceae): comparative results for allozymes and random amplified polymorphic DNA (RAPD) and inter-simple sequence repeat (ISSR) markers. Mol. Ecol, 8, 443-451. http://dx.doi.org/10.1046/j.1365-294X.1999.00585.x

Gajeraa, B. B., Kumara, N., Singha, A. S., Punvara, B. S., Ravikirana, R., Subhasha, N., Jadejab, G.C. (2010). Assessment of genetic diversity in castor (Ricinus communis L.) using RAPD and ISSR markers. Industrial Crops and Products, 32, 491-498. http://dx.doi.org/10.1016/j.indcrop.2010.06.021

Gonzalez, A., Coulson, A., Brettell, R. (2002). Development of DNA markers (ISSRs) in mango. Acta Hortic., 575, 139-143.

Gwanama, C., Labuschagne, M.T., Botha, A.M. (2000). Analysis of genetic variation in Cucurbita moschata by random amplified polymorphic DNA (RAPD) markers. Euphytica, 113, 19-24. http://dx.doi.org/10.1023/a:1003936019095

Jeong, G.T., Park, D.H. (2009). Optimization of biodiesel production from castor oil using response surface methodology. Appl. Biochem. Biotechnol., 156, 431441. http://dx.doi.org/10.1007/s12010-008-8468-9

Kallamadi, P. R., Nadigatlab, G. R., Mulpurib, S. 2015. Molecular diversity in castor (Ricinus communis L.). Industrial Crops and Products, 66, 271-281. http://dx.doi.org/10.1016/j.indcrop.2014.12.061

Kapteyn, J., Simon, J.E. (2002). The use of RAPDs for assessment of identity, diversity and quality of Echinacea. In: Janick, J., Whipkey, A. (Eds.), Trends in New Crops and New Uses. ASHS Press, Alexandria, VA, pp. 509-513.

Labajová, M., Senková, S., Žiarovská, J., Ražná, K., Bežo, M., Štefúnová, V., Zeleňáková, L. (2011). The potential of ISSR markers in amaranth gammaradiance mutants genotypying. Journal of Microbiology, Biotechnology and Food Sciences, 1, 507-521.

Landergott, U., Holderegger, R., Kozlowski, G., Schneller, J J. (2001). Historica bottlenecks decrease genetic diversity in natural populations of Dryopteris cristata. Heredity, 87, 344-355. http://dx.doi.org/10.1046/j.13652540.2001.00912.x

Li, F.J., Wang, C.L., He, D., Liu, Z.Q., Chen, M.H., Wang, Y.R., Li, F.J., Yang, Z.H., Chen, G. (2011). Evaluation of genetic diversity in Castor (Ricinus communis L.) using RAPD markers. Advanced materials research, 343-344, 981987. http://dx.doi.org/10.4028/www.scientific.net/amr.343-344.981

Machado, E.L., Silva, S A., Santos, A. S., Bastos, L. A., Pestana, C. N., Dos Santos K. S., Ferreira, C. F., Diamantino, M. S. A. S. (2013). Genetic dissimilarity between castor bean cultivars using RAPD markers. Pesq. agropec bras., 48(3), 342-345. http://dx.doi.org/10.1590/s0100-204x2013000300014

Paetkau, D., Calvert, W., Stirling, I. Strobeck, C. (1995). Microsatellite analysis of population structure in Canadian polar bears. Mol. Ecol., 4, 347-354 http://dx.doi.org/10.1111/j.1365-294x.1995.tb00227.x
Parsons, B.J., Newbury, H.J., Jackson, M.T., Ford-Lloyd, B.V. (1997) Contrasting genetic diversity relationships are revealed in rice (Oryza sativa L.) using different marker types. Mol. Breed., 3, 115-125. http://dx.doi.org/10.1023/A:1009635721319

Pecina-Quinteroa, V., Anaya-Lópeza, J. L., Núnez-Colína, C. A., ZamarripaColmenerob, A., Montes-Garcíac, N., Solís-Bonilla, J. L., Aguilar-Rangel, M. R. (2013). Assessing the genetic diversity of castor bean from Chiapas, México using SSR and AFLP markers. Industrial Crops and Product., 41, 134- 143 http://dx.doi.org/10.1016/j.indcrop.2012.04.033

Penner, G.A., (1996). RAPD analysis of plant genomes. Jauhar, P.P. (Ed.), Methods of Genome Analysis in Plants. CRC, Boca Raton, 251-268.

Reif, J.C., Gumpert, F.M., Fischer, S., Melchinger, A.E. (2007). Impact of interpopulation divergence on additive and dominance variance in hybrid populations. Genetics,

http://dx.doi.org/10.1534\%2Fgenetics.107.074146

Santalla, M., Power, J.B., Davey, M.R. (1998). Genetic diversity in mungbean germplasm revealed by RAPD markers. Plant Breed., 117, 473-478. http://dx.doi.org/10.1111/j.1439-0523.1998.tb01976.x

Sailaja, M., Tarakeswari, M., Sujatha, M. (2008). Stable genetic transformation of castor (Ricinus communis L.) via particle gun-mediated gene transfer using embryo axes from mature seeds. Plant Cell Rep., 27, 1509-1519. http://dx.doi.org/10.1007\%2fs00299-008-0580-3

Tomar Rukam, S., Parakhia, M. V., Kavani, R. H., Dobariya, K. L., Thakkar, J. R., Rathod, V. M., Dhingani, R. M. And Golakiya, B. A. (2014). Characterization of castor (Ricinus communis L.) genotypes using different markers. Res. J. Biotech, 9 (2), 6-13.

Vivodík, M., Balážová, Ž., Gálová, Z. (2014). RAPD analysis of the genetic diversity of castor bean. International journal of biological, veterinary, agricultural and food engineering. 8(7), 583-586.

Weber, J. L. (1990). Informativeveness of human (dC-dA)n x (dG-dT)n polymorphism. Genomics, 7, 524-530. http://dx.doi.org/10.1016/0888 7543(90)90195-Z

Weir, B.S. (1990). Genetic data analysis. Sinauer Associated, Sunderland, Mass. Welsh, J., Mcclelland, M. (1990). Fingerprinting genomes using PCR with arbitrary primers. Nucleic Acids Res., 18, 7213-7218 http://dx.doi.org/10.1093/nar/18.24.7213 